Copyright (C) 2018 by Academic Publishing House Researcher

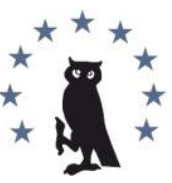

Published in the Russian Federation

European Researcher. Series A

Has been issued since 2010.

ISSN 2219-8229

E-ISSN 2224-0136

2018, 9(2): 132-143

DOI: $10.13187 /$ er.2018.2.132

www.erjournal.ru

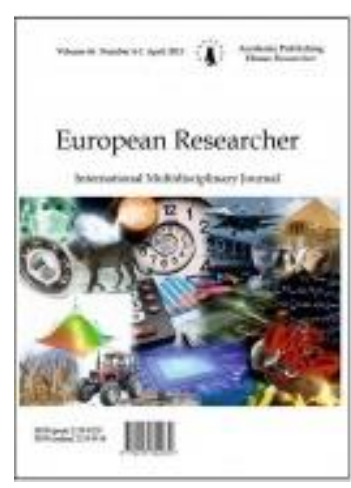

\title{
Analysis of References as a Method of Studying Scientific Connections on Example of Works of O.A. Dobiash-Rozhdestvenskaia (1874-1939)
}

\author{
Konstantin A. Minenko a, * \\ ${ }^{a}$ Saint-Petersburg State University, Institute of Philosophy, Russian Federation
}

\begin{abstract}
This paper will explore the theme of using analysis of references as a method of studying scientific connections. We will show, how exactly this method can be used when studying works of Russian historians of the late XIX - early XX centuries. In this paper we will analyze a work by a remarkable Russian historian and paleographer O. A. Dobiash-Rozhdestvenskaia named "Western pilgrimages in the Middle Ages". Through the references in this work we will learn, which studies have had the most impact on Dobiash-Rozhdestvenskaia when she was writing her work. We will also research these studies and their authors, their perception of history and scientific background. The results of our analysis will help us to make some conclusions regarding the influence of French and German historiographical traditions on Russian science.
\end{abstract}

Keywords: history of science, Dobiash-Rozhdestvenskaia, medieval studies, references.

\section{1. Введение}

Проблематика взаимовлияний разных историографических традиций и методологий неоднократно изучалась. Отечественные историки неоднократно обращались к трудам своих иностранных коллег, что позволяет проследить влияние на них тех или иных исследователей.

В рамках нашего исследования приоритетом станет контекстуальный анализ справочного аппарата, а не основного текста работы. Основное внимание обращено на научное наследие Ольги Антоновны Добиаш-Рождественской (1874-1939), являвшейся одним из крупнейших отечественных медиевистов XX в. Она - основатель источниковедческой школы, которая развивалась в рамках Ленинградской Публичной Библиотеки и Ленинградского университета. Добиаш-Рождественская привнесла в российскую науку методы работы с источниками, которые она восприняла, находясь в научной командировке во Франции, в Сорбонне. Она обучалась в Национальной школе хартий (Ecole nationale des chartes), где слушала лекции выдающихся французских историков, среди которых были Шарль-Виктор Ланглуа (Charles-Victor Langlois, 1863-1929) и Фердинанд Лот (Ferdinand Lot, 1866-1952).

Французская историография оказала значительное влияние на ДобиашРождественскую. Так как труды Добиаш-Рождественской очень важны для всей последующей отечественной исторической науки, на наш взгляд, было бы полезно

\footnotetext{
${ }^{*}$ Corresponding author

E-mail addresses: koxminenko@gmail.com (K.A. Minenko)
} 
проследить, какие именно французские историки оказали наибольшее влияние на саму Ольгу Антоновну.

\section{2. Материалы и методы}

Для реализации данной задачи мы постараемся использовать несколько иную методику, а именно анализ справочного аппарата. Сноски, могут рассказать многое об авторе исследования: какие концепции на него повлияли, какой литературой он пользовался, что послужило источником для его работы и так далее. В данной статье мы применим к сноскам принципы, положенные в основу изучения средневековых маргиналий и глосс Раннего Нового времени (об истории справочного аппарата см.: Connors, 1998; Connors, 1999; Grafton, 1994).

Если на сегодняшний день способы оформления сносок унифицированы, то во второй половине XIX в. определенная традиция существовала, тем не менее, она не была единой для всех исследований. Помимо исключительно формальных моментов в использовании сносок, нас также будут интересовать насколько часто автор ими пользовался, каков был характер этих ссылок, наконец, для чего он вводил их. Однако, самым важным для нас остается вопрос о том, на какие произведения ссылались отечественные историки и почему они предпочли их другим. Для ответа на эти вопросы нам необходимо рассмотреть труды конкретных авторов, обращая при этом внимание на то, каких концепций они придерживались, в какой парадигме работали.

Мы рассмотрим работу Ольги Антоновны Добиащ-Рождественской «Западные паломничества в Средние века», которая была выпущена издательством Брокгауза и Ефрона в 1924 г. Выбор данного исследования связан с тем, что эта работа - последняя перед рядом других работ Ольги Антоновны, в которых она занималась проблемами палеографии. К более общим вопросам средневековой истории Западной Европы она вернется только в 1939 г., когда будет писать так и не опубликованную при ее жизни «Духовную культуру Западной Европы IV-XI веков». Так как работы Добиаш-Рождественской по палеографии носят специальный характер, мы сочли, что было бы уместно обратиться к сочинению, в котором она бы более полно раскрывала свое видение средневековой истории. Как раз таким сочинением, несмотря на свой небольшой размер, являются «Западные паломничества в Средние века».

\section{3. Обсуждение}

И стилистика текста «Западных паломничеств в Средние века», и малое количество ссылок говорят нам о том, что это скорее пример научно-популярной литературы, чем строго научного сочинения. Материала для анализа справочного аппарата в этой работе будет не так много, но, тем не менее, он может оказаться весьма любопытным: малое количество ссылок делает их особенно ценными - автор по какой-то причине все-таки решил их привести. Как раз причина появления ссылки на страницах сочинения нас и интересует.

Первая ссылка, которую дает Добиаш-Рождественская в «Западных паломничествах в Средние века», это ссылка на исследование Ашиля Люшера (Achille Luchaire, 1846-1908) «Первые Капетинги» («Les premiers Capetiens»), изданную в рамках многотомной «Истории Франции» Эрнеста Лависса (Ernest Lavisse, 1842-1922) в 1901 г. Приведем здесь сноску в том виде, в котором ее дает Добиаш-Рождественская, а рядом с ней соответствующую цитату из работы Люшера:

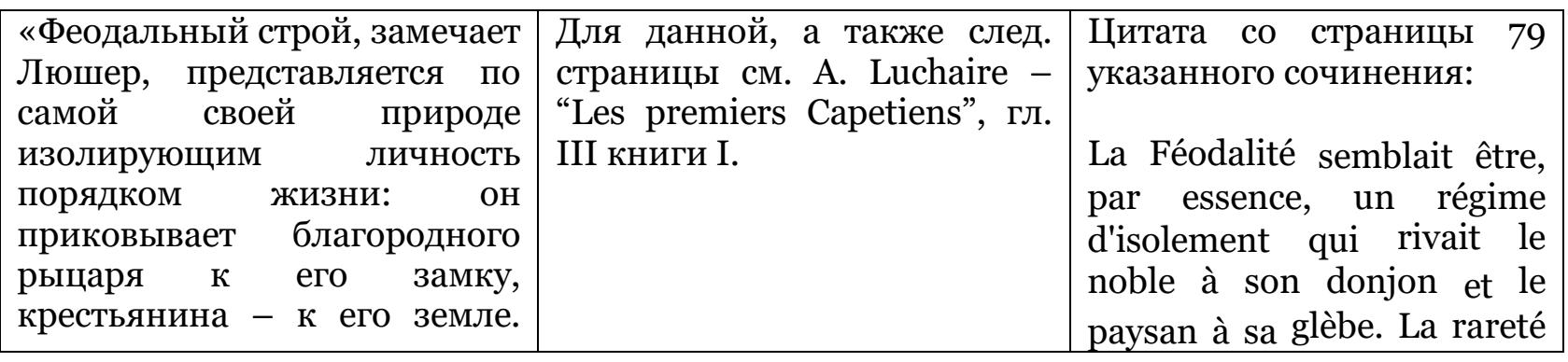




\begin{tabular}{|c|c|}
\hline 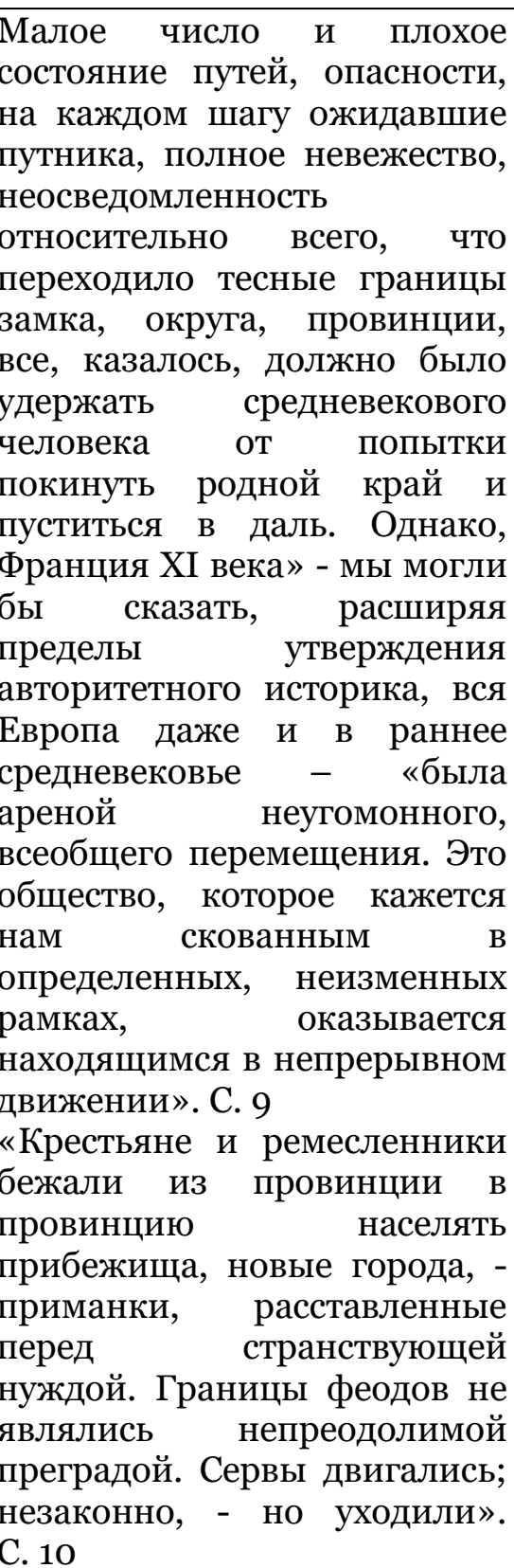 & $\begin{array}{l}\text { et le mauvais état des roules, } \\
\text { les périls variés qui } \\
\text { attendaient le voyageur à } \\
\text { chaque pas, l'ignorance de ce } \\
\text { qui dépassait l'horizon } \\
\text { immédiat du château, du } \\
\text { canton ou de la province, } \\
\text { tout semblait dissuader } \\
\text { l'homme du Moyen âge de } \\
\text { quitter le pays natal et de } \\
\text { s'aventurer au loin. Et } \\
\text { pourtant, la France du xi'me } \\
\text { siècle a été le théâtre d'une } \\
\text { circulation continue, } \\
\text { générale, intense au delà de } \\
\text { ce qu'on peut imaginer. } \\
\text { Cette société, qu'on croyait } \\
\text { figée dans ses cadres, } \\
\text { apparait toujours en } \\
\text { mouvement. } \\
\text { Ha crpaHuцe 8o: } \\
\text { Paysans et artisans } \\
\text { couraient, de province en } \\
\text { province, peupler les lieux } \\
\text { d'asile, les villes neuves, } \\
\text { appâts semés devant la } \\
\text { misère ambulante. Les } \\
\text { frontières des fiefs n'étaient } \\
\text { pas une barrière } \\
\text { infranchissable. Les serfs se } \\
\text { remuaient illégalement, } \\
\text { mais ils se remuaient. }\end{array}$ \\
\hline
\end{tabular}

Как мы видим, в своей работе Добиаш-Рождественская приводит почти прямой перевод текста Люшера и использует его в том же контексте, что и он. ДобиашРождественская приводит мнение Люшера в качестве довода против устоявшегося образа средневековья как эпохи застоя, когда человек всю свою жизнь проводил на одном месте. Возможно, она решила обратиться к Люшеру из-за его авторитета как выдающегося французского историка. Неслучайно она так и называет его - «авторитетный историк» (Добиаш-Рождественская, 1924).

Рассмотрим же повнимательнее фигуру Ашиля Люшера. В 1866 году он поступил в Высшую нормальную школу, в 1869 году получил степень агреже по истории, после чего преподавал в лицеях По и Бордо (Necrologie). В 1879 году он начал работать на факультете филологии университета Бордо (Necrologie). Его первое крупное исследование было опубликовано в 1877 году и называлось «Ален Великий, сеньор д'Альбре» («Alain le Grand, sire d'Albret»). Эта работа - докторская диссертация Люшера. Он также активно занимался лингвистикой: его работы «Изучение пиренейских идиом во французском регионе» («Etude sur les idioms pyreneens de la region francaise», Paris, 1879) и «Сборник текстов на древнем диалекте гасконского языка» («Recueil de textes de l'ancien dialecte gascon», Paris, 1881) 
долгое время были главными исследованиями по своей теме (Necrologie). В Бордо Люшер начал работу по изучению истории Франции при первых Капетингах, которая заслужила ему признание в среде медиевистов (Necrologie). В 1885 году Люшер был приглашен в Сорбонну (Necrologie). Там он читал курс по вспомогательным наукам истории, а в 1889 году сменил Фюстеля де Куланжа во главе кафедры истории средних веков (Necrologie). Последние годы жизни Люшер посвятил написанию труда по истории понтификата папы Иннокентия III. Последний, шестой, том этой работы он закончил буквально за несколько дней до смерти (Necrologie).

Свое исследование «Первые Капетинги» Люшер разделил на две книги: феодализм и церковь (XI век) и французский Ренессанс (конец XI и начало XII века). Каждая книга, в свою очередь, делится на главы, посвященные отдельным аспектам французского общества указанного периода. Так, в первой части работы Люшера есть такие главы: «Феодальный режим», «Великие сеньоры и провинциальные династии», «Французская знать за пределами Франции», «Церковь», «Четыре первых Капетинга», «Цивилизация». Уже по самим названиям глав мы можем видеть, что Люшер рассматривал историю Франции при Капетингах под разными углами и с разных точек зрения. Мы можем предположить, что его намерением было изложить историю Франции XI-XII веков максимально полно, не столь заостряя внимание на специальных вопросах. Это вполне вписывается в концепцию серии книг о французской истории Лависса, в рамках которой и были опубликованы «Первые Капетинги».

Главы работы Люшера в свою очередь поделены им на параграфы, каждый из которых он сопровождает сноской, в которой указывает сочинения, посвященные теме параграфа. Добиаш-Рождественская ссылается на первый параграф третьей главы первой части «Первых Капетингов», который озаглавлен «Феодальный мир в движении. Паломничества». Перечислим работы, с которыми Люшер предлагает ознакомиться по данной теме: «О паломничествах в Святую землю до Крестовых походов» («Des pelerinages en Terre-Sainte avant les croisades» в Bibl. de l'Ecole des Chartes, 1845) Людовика Лаланна (Ludovic Lalanne, 1815-1898) и «Паломничества к Святой земле до Крестовых походов» («Die Pilgerfahrten nach dem heiligen Lande vor den Kreuzzugen», 1875) Рейнхольда Рёрихта (Reinhold Roehricht, 1842-1905). Ссылка на эти работы - единственная в этом параграфе; в остальных главах Люшер тоже прибегает к справочному аппарату только в начале параграфов. Это может быть еще одним свидетельством того, что «Первые Капетинги» обзорная работа, в общем виде обрисовывающая различные аспекты истории Франции XIXII веков, а не сочинение, рассматривающее специальные темы.

То, что Люшер дает ссылку на работы Лаланна и Рёрихта, говорит нам кое-что и о нем самом. Людовик Лаланн - французский историк и библиотекарь (о нем см.: Barthelemy, 1898), получивший образование в Национальной школе хартий (l’Ecole nationale des chartes). Школа хартий - это ведущий центр палеографии в конце XIX - начале XX века; именно там проходила стажировку Добиаш-Рождественская, которая восприняла традицию французской школы палеографии и перенесла ее в Россию.

При написании своей работы Добиаш-Рождественская активно использовала исследование графа Поля Рианта (Paul Riant, 1836-1888) под названием «Экспедиции и паломничества скандинавов в Святую землю во времена крестовых походов» («Expeditions et pelerinages des Scandinaves en terre sainte au temps des croisades», Paris, 1865). Такой вывод мы можем сделать, основываясь на этой ссылке:

\begin{tabular}{|c|c|c|}
\hline $\begin{array}{l}\text { «Всякого, кто вчитывается в } \\
\text { разнообразные источники } \\
\text { истории средневекового } \\
\text { Севера, особенно поражает та } \\
\text { таинственная притягательная } \\
\text { сила, с какою Восток } \\
\text { действовал на дух народов } \\
\text { Скандинавии, начиная с } \\
\text { самых отдаленных времен, }\end{array}$ & $\begin{array}{l}\text { В стран. } 13-73 \text { мы } \\
\text { опираемся на сочинение } \\
\text { Riant. - Expeditions et } \\
\text { pelerinages des Scandinaves en } \\
\text { Terre Sainte etc”. Paris. } 1865 \text {. }\end{array}$ & $\begin{array}{l}\text { Цитата со страницы } 14 \\
\text { указанного сочинения: } \\
\text { Un des principaux faits qui } \\
\text { frappent le lecteur dans } \\
\text { l'etude de ces differentes } \\
\text { sources de l'histoire du } \\
\text { Nord, est l'attraction } \\
\text { singuliere que l'Orient parait } \\
\text { avoir exercee sur l'esprit des }\end{array}$ \\
\hline
\end{tabular}




\begin{tabular}{|l|l|l|}
\hline упорная жизненность в & \\
народном предании какой-то & & Scandinaves depuis les \\
мистической идеи, связанной & temps les plus recules, et la \\
с далекою страною, где встает & persistance, a travers toutes \\
солнце». С. 11 & $\begin{array}{l}\text { les traditions nationales, } \\
\text { d'une idee mystique } \\
\text { attachee aux pays lointains } \\
\text { ou le soleil se leve. }\end{array}$ \\
\hline
\end{tabular}

Как мы видим, Добиаш-Рождественская приводит вольный перевод того текста, который мы видим у Рианта. Учитывая, что весь текст сочинения Добиаш-Рождественской занимает 73 страницы, очевидно, что она на протяжении всего своего исследования обращалась к работе Рианта.

В связи с этим, нам необходимо рассмотреть фигуру этого автора. Граф Поль Риант получил образование в иезуитском колледже Вожирард (College de Vaugirard), после чего получил докторскую степень на филологическом факультете Сорбонны (D' Hervey de Saint Denys, 1888). Используемая Добиаш-Рождественской работа Рианта - это его докторская диссертация. Его монография заслужила ему признание на севере Европы, где оценили его вклад в изучение истории участия скандинавов в крестовых походах (Moller, 2007). В 1865 году, когда была опубликована его докторская диссертация он стал членом шведской королевской академии наук (Moller, 2007). В 1867 году он также был принят в датскую академию наук (Moller, 2007). Финансовые возможности графа, а также знание им, помимо латыни и древнегреческого, скандинавских языков позволяли ему заниматься переводом и публикацией манускриптов и рукописей, найденных им в коллекциях библиотек и учебных заведений Северной Европы (Moller, 2007). В 1875 году он основал Общество латинского Востока (Societe de l'Orient Latin), в пользу которого жертвовал значительные суммы из собственных средств (Moller, 2007).

Монография «Экспедиции и паломничества скандинавов в Святую землю во времена крестовых походов» стала своего рода соединением двух интересов Рианта: интереса к крестовым походам и интереса к Северной Европе. Свою работу он начинает с того, что обрисовывает современный ему взгляд на участие скандинавов в крестовых походах: устоявшимся мнением было, что скандинавские королевства не оставили сколько-нибудь значимого следа в крестоносном движении. Риант делает обзор литературы по данной теме, а также описывает основные источники для своего исследования, которыми являются исторические саги и хроники юридические документы скандинавского происхождения, мифические саги и эпос, шведские и датские документы на латыни, а также хроники остальных европейских стран (Riant, 1865). Помимо текстовых источников, Риант обращается к данным археологии: в своем сочинении он исследует латинские надписи, имеющие отношение к северным паломникам (Riant, 1865). Риант рассматривает процесс христианизации скандинавского фольклора и отождествления Святой земли и Иерусалима с некоторыми локусами скандинавской мифологии. По тому же пути в своем сочинении идет Добиаш-Рождественская. Оба автора отмечают восприятие Востока скандинавами в качестве мистической страны, населенной богами. Вероятно, что эту идею Добиаш-Рождественская подчерпнула в работе Рианта, а потом развила в собственном сочинении.

Приведем здесь другие ссылки Добиаш-Рождественской на Рианта:

\begin{tabular}{|c|c|c|}
\hline 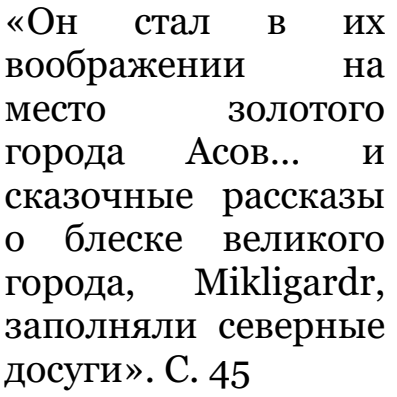 & Riant, стран. 68. & $\begin{array}{l}\text { Byzance, qui remplaçait, aux yeux des Scandinaves } \\
\text { devenus chrétiens, la ville d'or des Ases, était une } \\
\text { cité sainte, vénérée dans les trois royaumes, à l'égal } \\
\text { de Rome; de fabuleux récits des splendeurs de la } \\
\text { grande ville, «Mikligardr,» remplissaient les } \\
\text { veillées du Nord; }\end{array}$ \\
\hline
\end{tabular}




\begin{tabular}{|c|c|c|}
\hline $\begin{array}{lr}\text { «Там стоит храм } \\
\text { святой } \\
\text { великолепнейший } \\
\text { из всех храмов мира. } \\
\text { Там хранится } \\
\text { подлинный крест, } \\
\text { там } \quad \text { покоятся } \\
\text { Филипп и Иаков, } \\
\text { там ясли спасителя». } \\
\text { С. } 46\end{array}$ & $\begin{array}{l}\text { См. выше стран. } \\
15\end{array}$ & $\begin{array}{l}\text { Цитату обнаруживаем на } 68 \text { странице } \\
\text { сочинения Рианта: } \\
\text { Apres avoir parle de Sainte-Sophie, qu'il appellee } \\
\text { AEgisif ..., «le temple le plus splendide du monde, } \\
\text { et ou l'on conserve le vraie croix: dans la meme } \\
\text { ville, dit-il, reposent Philippe et Jacques, Luc et } \\
\text { Timpthee; on y venere la main droite d'Etienne, la } \\
\text { sainte tunique, les chefs d'Abraham, d'Isaac et de } \\
\text { Jacob, la crèche du Seigneur, ...» }\end{array}$ \\
\hline
\end{tabular}

Мы можем только предполагать, что вызвало такую ошибку в указании страницы, с которой была взята цитата. В связи с этим остановимся на том, что это, вероятно, опечатка.

Фрагменты текста, которые Добиаш-Рождественская подкрепляет цитатами из Рианта, тоже развивают тему переноса привычных языческих мифологем скандинавов в христианский универсум. Еще одна ссылка на Рианта предназначена для читателя: работа Рианта предлагается ему как источник сведений о морских маршрутах, проложенных скандинавскими воинами и купцами.

Еще одна работа, которой Добиаш-Рождественская пользовалась при написании «Западных паломничеств в Средние века» - это сочинение Луи Брейе (Louis Brehier, 18681951) «Церковь и Восток в Средние века. Крестовые походы» («L'Eglise et l'Orient au Moyen Age. Les Croisades», 1921). Как мы можем видеть, Брейе - представитель более позднего поколения, чем большинство упоминаемых нами здесь исследователей. Луи родился в семье преподавателя лицея в Бресте, его младший брат Эмиль (Emile Brehier, 1876-1952) известный философ и историк философии, член Академии моральных и политических наук (L'Academie des Sciences morales et politiques) (Salin, 1954). В Сорбонне Луи Брейе учился у Жиро, Сеньобоса и Лависса (Salin, 1954). В 1892 г. он получил степень агреже после защиты диссертации по теме «Греческое общество современное Илиаде и Одиссее» («La Societe grecque contemporaine de l”Iliade et de l'Odyssee») (Salin, 1954). В свободное от своих прямых обязанностей время Брейе переводил античные трагедии (Salin, 1954). Докторскую степень он получил в возрасте 31 года (в марте 1899 г.) за защиту диссертации «Восточная схизма в XI веке» («La schisme oriental au XIe siecle») и латинской диссертации «De graecorum judiciorum origine» (Salin, 1954). Вскоре после этого он получил назначение на факультет филологии в университете Клермонта, где он читал курсы по истории и географии древности и средневековья. Брейе активно участвовал в международных конгрессах и конференциях, посвященных вопросам археологии, ездил в командировки и экспедиции (Salin, 1954).

Приведем ниже ссылки, которые Добиаш-Рождественская дает на работу Брейе:

\begin{tabular}{|c|c|c|}
\hline «Восстановление & - "L’Eglise & Цитата обнаружива \\
\hline Константине & l'Orient”. & странице \\
\hline Диоклетиане не могло вернуть & & сочинения: \\
\hline латинской & & La restauration de l'empire \\
\hline утраченной силы и здоровья. & & par les Dioclétien et les \\
\hline Перенося седалище империи, & & Constantin n'a pu rendre à la \\
\hline $\begin{array}{l}\text { еe столицу, в Византию, } \\
\text { Константин Великий только }\end{array}$ & & culture latine sa vigueur \\
\hline санкционировал фактически & & siège de l'empire romain à \\
\hline преобладание & & Byzance, Constantin n'a fait \\
\hline востока над западом. При его & & que consacrer officiellement \\
\hline $\begin{array}{l}\text { преемниках, несмотря на } \\
\text { страшные потрясения, какие }\end{array}$ & & cette prééminence \\
\hline постигли восточную империю, & & ident. Sous \\
\hline особенно & & quelques crises terribles qui \\
\hline полуостров, & & surtout \\
\hline
\end{tabular}




\begin{tabular}{|c|c|c|}
\hline $\begin{array}{lr}\text { сказать, в общем, остался } \\
\text { укрытым от } \\
\text { Византийская } \\
\text { явилась настоящим бастиономия } \\
\text { в отношении германского } \\
\text { варварства, и двукратно, в два } \\
\text { тяжелые } \text { момента ее } \\
\text { политические вожди сумели } \\
\text { повернуть от нее на Италию } \\
\text { бич готского нашествия». С. } 13\end{array}$ & & $\begin{array}{l}\text { péninsule des Balkans et la } \\
\text { Grèce, l'Orient est resté à } \\
\text { l'abri des invasions. } \\
\text { L'empire byzantin s'est } \\
\text { constitué comme une } \\
\text { véritable marche vis-à-vis de } \\
\text { la barbarie germanique et, à } \\
\text { deux reprises, ses politiques } \\
\text { ont su détourner vers l'Italie } \\
\text { le fléau de l'invasion } \\
\text { gothique. }\end{array}$ \\
\hline 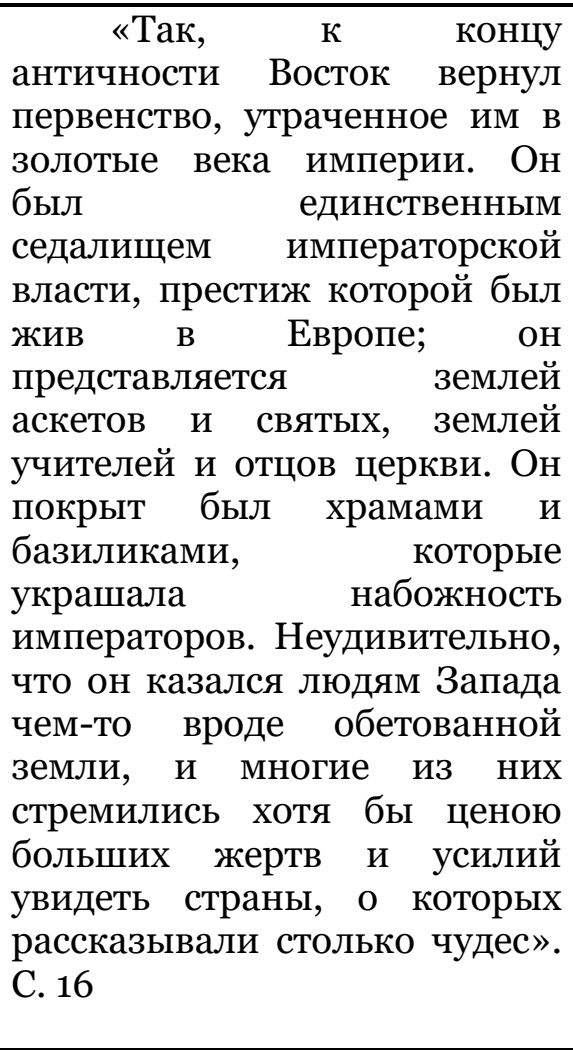 & Brehier, op. cit. & $\begin{array}{l}\text { Цитата на 5 странице } \\
\text { сочинения Брейе: } \\
\text { L'Orient est donc à la } \\
\text { fin de l'antiquité le centre } \\
\text { politique, le siège de la } \\
\text { domination impériale dont le } \\
\text { prestige est toujours vivant } \\
\text { en Europe; il est aussi la } \\
\text { terre des saints et des } \\
\text { ascètes, la patrie des grands } \\
\text { docteurs; il est couvert des } \\
\text { basiliques somptueuses } \\
\text { enrichies par la piété des } \\
\text { empereurs. Il ne faut donc } \\
\text { pas s'étonner qu'il apparaisse } \\
\text { aux Occidentaux comme une } \\
\text { sorte de Terre promise et que } \\
\text { beaucoup d'entre eux, même } \\
\text { au prix des plus pénibles } \\
\text { sacrifices, cher- chent à } \\
\text { entrevoir tout au moins ces } \\
\text { pays dont on raconte tant de } \\
\text { merveilles. }\end{array}$ \\
\hline
\end{tabular}

Как можно заметить, Добиаш-Рождественская не указывает страницу, с которой она берет цитату, приведенную в «Западных паломничествах в Средние века». Вместе с тем, эта цитата представляет собой почти дословный перевод того текста, который мы видим у Брейе. Безусловно, это вызывает вопрос: почему Добиаш-Рождественская не стала указывать страницу, с которой она брала цитату? На данный момент мы не видим возможности дать сколько-нибудь убедительный ответ на этот вопрос.

Исследование Луи Брейе «Церковь и Восток в Средние века. Крестовые походы» была издана в Париже в 1907 г. Это научное сочинение написано позже большинства других работ, на которые ссылается Добиаш-Рождественская. Если мы сравним его с исследованиями более раннего периода, мы сможем проследить эволюцию методов и техник написания научной работы, а также формирование своеобразного канона и традиции написания таких текстов. Так, у Брейе мы видим библиографию, которую он дает в начале каждой главы. Библиографию он всякий раз разделяет на источники и исследования (монографии). Также, отметим, что введение к работе Брейе представляет из себя, по сути, обзор источников по предмету исследования. Такое оформление работы заметно отличается от более ранних монографий: источники для исследования теперь с легкостью можно обнаружить сосредоточенными в одном месте в тексте.

Для нашего исследования важно то, что, судя по указанным им во введении научным 
работам, Брейе знал труды некоторых из уже упоминавшихся нами историков. В частности, он указывает (Brehier, 1907), что пользовался публикациями Общества латинского Востока, основателем которого был граф Поль Риант. В числе исследований, которыми Брейе пользовался больше всего при написании своей работы - «История крестовых походов» («Histoire des Croisades») Жозефа-Франсуа Мишо (Joseph-Francois Michaud, 1767-1840), a также «История крестовых походов в плане» («Geschichte der Kreuzzuge im Umriss») Рёрихта. Вновь мы видим знакомого нам автора: на Рёрихта ссылался и Поль Риант. Мы можем явно проследить связь этих трех авторов: Рианта, Рёрихта и Брейе. Еще одно свидетельство их взаимовлияния - заметка Рейнхольда Рёрихта на смерть Поля Рианта (Rohricht, 1889).

Информация, которую Добиаш-Рождественская приводит, цитируя Брейе, не является специальной, наиболее вероятно, что она просто подкрепляет мнение ДобиашРождественской. Как мы видим, обе цитаты взяты с первых страниц сочинения Брейе, когда он только вводит читателя в проблематику своего предмета. «Церковь и Восток в Средние века. Крестовые походы» - это по своему стилю строго научное сочинение, рассматривающее специальные вопросы медиевистики и ориенталистики, в то время как «Западные паломничества в Средние века» - это, как мы уже отмечали, скорее пример научно-популярной литературы, для которого важно дать общее представление о своем предмете. Возможно, именно из-за разницы в целях этих сочинений ДобиашРождественская так мало использовала труд Брейе.

Еще одно сочинение, которое Добиаш-Рождественская использовала при написании «Западных паломничеств в Средние века», - это «Эпические легенды. Исследование формирования chansons de geste» («Les legends epiques. Recherches sur la formation des chansons de geste») филолога-медиевиста Жозефа Бедье (Joseph Bedier, 1864-1938).

Жозеф Бедье - выпускник Высшей нормальной школы, в 1886 году получил звание агреже по филологии, в 1893 году получил уже докторскую степень по филологии (Charle, Telkès, 1988). Его диссертация называлась «Фаблио. Исследование народной литературы и письменной истории Средних веков» («Les fabliaux. Etudes de litterature populaire et d'histoire litteraire du Moyen Age») (Charle, Telkès, 1988). «Эпические легенды. Исследование формирования chansons de geste» - его самое крупное сочинение, вызвавшее бурное обсуждение в научном мире. Теория Бедье о происхождении chansons de geste проиграла спор своим оппонентам; против нее выступали испанский исследователь Менендез Пидаль (Ramon Menendez Pidal, 1869-1968) (см.: Bataillon, 1969) и Фердинанд Лот (см.: Lot, 1913).

Первый том «Эпических легенд» посвящен циклу песен о Гильоме Оранжском. Бедье обращается к различным средневековым источникам в поисках информации о паломнической дороге, которая упоминается в одной из песен о Гильоме.

Приведем ниже ссылку, которую Добиаш-Рождественская дает на Бедье:

\begin{tabular}{|c|c|c|}
\hline $\begin{array}{l}\text { «Как велик должен был } \\
\text { быть их прилив к главным } \\
\text { этапам, туда, где все было } \\
\text { организовано } \\
\text { главных святилищ, чколо } \\
\text { принять и удержать их!». } \\
\text { С. } 55\end{array}$ & $\begin{array}{l}\text { Bedier. - "Les legends } \\
\text { epiques", т. I, ch. XI-me (Via } \\
\text { tolosana), pp. } 365 \text { sqq. }\end{array}$ & $\begin{array}{l}\text { Цитата обнаруживается на } \\
\text { з39 странице указанного } \\
\text { сочинения: } \\
\text { Quelle devait être leur affluence } \\
\text { aux principales étapes, là où tout } \\
\text { était organisé, autour des grands } \\
\text { sanctuaires, pour leur faire } \\
\text { accueil et les retenir! }\end{array}$ \\
\hline
\end{tabular}

Как и в иных случаях, единственное объяснение ошибки при цитировании, которое мы можем дать - это опечатка.

Описание Тулузской дороги паломников, данное Добиаш-Рождественской в «Западных паломничествах в Средние века», тоже, вероятно взято ей из текста Бедье. Более того, мы можем это с уверенностью утверждать, так как текст Добиаш-Рождественской представляет собой почти дословный перевод того, что мы находим у Бедье. Чтобы не быть голословными, приведем здесь фрагменты текста обоих авторов: 
Страницы 340-341 сочинения Бедье:

De Nimes, si ces pelerins vont a Saint-Gilles de Provence, comme leur Guide le conseille, ils vont a Arles. La ils prennent la voie Domitienne qui, partant d'Arles, traverse Nimes, Montpellier, Beziers, Narbonne.

A Narbonne, ils prennent la route que suivant en sens inverse, des 333, le chretien qui nous a laisse son itineraire de Bordeaux a Jerusalem, et c'est la route si souvent qualifee de ces noms: chemin roumieu, caminus peregrinus, caminus romeus sancti Jacobi. Elle les conduit a Toulouse par Lezignan et Carcassonne.

De Toulouse, la grande voie de penetration, si l'on veut traverser la partie centrale des Pyrenees, est la vallee de la Garonne, soit qu'on veuille gagner le port aujourd'hui presque abandonne de Tenarese, soit plutot que l'on aille jusqu'a Dax pour se deriger sur le port d'Aspe ou sur Roncevaux: on remontait la vallee de la Garonne par l'ancienne voie romaine ou l'Itineraire Antonin marque, entre autres stations, celles de Calagorgis ou Calaguris et d'Aquae Siccae.
Страница 54 «Западных паломничеств в Средние века»:

От Нима, если паломник желает зайти в СенЖиль, как ему советует его дорожник, он направится на Арль. Отсюда он пустится по Домициевой дороге, которая, выйдя из Арля, пересекает Ним, Монпелье, Безье, Нарбонну. От Нарбонны путник следовали той самой дорогой, по которой, в обратном направлении, прошел в 333 году благочестивый человек, оставивший дорожник «из Бордо в Иерусалим». Эта дорога часто является (в текстах) под названием chemin roumieu, caminus peregrinus, caminus romvus Sancti Jacobi. Она ведет в Тулузу через Лезиньян и Каркассонну.

Отсюда, если путешественники желали пересечь центральный массив Пиренеев, большой дорогой являлась долина Гаронны...

Ссылка на Бедье, которую дает Добиаш-Рождественская, относится не к этому фрагменту, а цитате, заключенной в кавычки, которую она приводит дальше в своем тексте. Остается неизвестным, почему Добиаш-Рождественская не процитировала работу Бедье, а просто скопировала его текст, без всяких указаний на источник.

Вместе с тем, важно отметить, что текст, позаимствованный Добиаш-Рождественской у Бедье, носит информативный характер: он не содержит в себе следов позиции автора по какому-либо вопросу, а только излагает то, что известно о средневековых маршрутах паломников из разнообразных дорожников.

Хотя Добиаш-Рождественская в предисловии к «Западным паломничествам в Средние века» пишет «когда мы цитируем современных авторов, мы всегда указываем их в примечании» (Добиаш-Рождественская, 1924), в данном случае мы не видим не кавычек, обрамляющих текст, ни сноски, где приводилась бы ссылка на автора.

Отметим также еще две ссылки, которые Добиаш-Рождественская дает в своей работе. Это ссылки на немецких исследователей Карла Альбрехта Бернулли (Carl Albrecht Bernoulli, 1868-1937) и Фридриха фон Бецольда (Friedrich von Bezold, 1848-1928). Работа Бернулли «Святые Меровингов» («Die Heiligen der Merowinger», 1900) интересна нам тем, что Добиаш-Рождественская будет ссылаться на нее и в более поздних своих работах. «История Реформации в Германии» Бецольда - это редкий пример переведенного на русский язык исследования, которым пользовалась Добиаш-Рождественская.

\section{4. Результаты}

Подводя итоги анализа справочного аппарата в работе Добиаш-Рождественской «Западные паломничества в Средние века», мы можем заключить, что оформлен он не лучшим образом. Допущено несколько ошибок при цитировании, некоторые фрагменты текста явно взяты из другого исследования, но при этом даны без ссылки. Вместе с тем, важно отметить, что эта работа - пример научно-популярной литературы, и многие наши претензии к справочному аппарату в ней отпадают после прочтения предисловия. «Мы не нашли возможным обременять книгу, уснащая ее ссылками на многочисленные источники. 
Она предназначалась для самой широкой публики, и самый печатный станок вряд ли мог бы легко выдержать все это множество специальных указаний» (Добиаш-Рождественская, 1924) - так сама Добиаш-Рождественская объясняет характер этой работы и ее справочного аппарата. Однако, отметим, что, на наш взгляд, в некоторых случаях в этом исследовании не хватает ссылок, даже учитывая замечания автора в предисловии.

\section{5. Заключение}

Основываясь на проведенном анализе, мы можем утверждать, что очевидно влияние на Ольгу Антоновну французской и немецкой историографий. Немецкая историческая школа имела огромное значение для всей дореволюционной российской историографии, а Добиаш-Рождественская оставалась в русле этой традиции, даже несмотря на то, что большая часть ее научной деятельности проходила уже в СССР. Связь же ДобиашРождественской с французскими историками легко объясняется через факты ее биографии. Такая принадлежность к западноевропейской научной традиции прослеживается и в более поздних трудах Ольги Антоновны.

Хотелось бы особенно подчеркнуть то, что за каждым историческим исследованием стоит автор, который имеет определенную методологическую позицию и определенное восприятие истории. Так, большинство работ, на которые ссылается ДобиашРождественская, принадлежат перу историков-позитивистов. Для них характерно внимание к текстам и восприятие их как источников знания о том, как все было «на самом деле». Критическое восприятие текстов характерно для более поздних направлений в исторической науке - например для школы «Анналов», образовавшейся во Франции в 1920-х гг. Авторитет и выдающаяся работа Добиаш-Рождественской определили линию развития отечественного источниковедения, которая генеалогически восходит к позитивистской традиции конца XIX века.

Таким образом, мы полагаем, что на примере анализа справочного аппарата в работе Ольги Антоновны Добиаш-Рождественской «Западные паломничества в Средние века» мы убедительно доказали преимущества использования такой методологии, которая позволяет проследить научные связи и может быть применена к огромному массиву материала. Анализируя справочный аппарат, мы можем с уверенностью утверждать, использовалась ли та или иная работа автором, насколько часто он к ней обращался и так далее. Используя полученную информацию в сочетании с фактами биографии автора мы можем составить довольно четкое представление о тех влияниях, которые он испытывал при написании своей научной работы.

\section{Литература}

Barthelemy, 1898 - Barthélémy A. Ludovic Lalanne. Bibliothèque de l'école des chartes. 1898, T. 59, 589-598.

Bataillon, 1969 - Bataillon Ml. D.R. Menéndez Pidal (1869-1968). Bulletin Hispanique, 1969, T. 71, No. 1-2, 441-451.

Brehier, 1907 - Brehier L. L'Eglise et l'Orient au Moyen Age. Les croisades. Paris: Librairie Victor Lecoffre, 1907.

Charle, Telkes, 1988 - Charle C., Telkès E. Bédier (Charles, Marie, Joseph). Les professeurs du Collège de France - Dictionnaire biographique 1901-1939. Paris: Institut national de recherche pédagogique, 1988, 31-32.

Connors, 1998 - Connors R. $J$. The rhetoric of citation systems - Part I: The development of annotation structures from the renaissance to 1900. Rhetoric Review, 1998, 17(1), 6-48.

Connors, 1999 - Connors R.J. The rhetoric of citation systems - Part II: Competing epistemic values in citation. Rhetoric Review., 1999, 17(2), 219-245.

D’ Hervey de Saint Denys, 1888 - D' Hervey de Saint Denys L. Éloge funèbre de M. le comte Paul-Édouard-Didier Riant, membre de l'Académie. Comptes rendus des séances de l'Académie des Inscriptions et Belles-Lettres, 32e année, 1888, N. 6, 473-476.

Grafton, 1994 - Grafton A. The Footnote from De Thou to Ranke. History and Theory, 1994, vol. 33 , no. $4,53-76$. 
Lot, 1913 - Lot F. Joseph Bédier, Les légendes épiques. Recherches sur la formation des Chansons de geste; 1908-1913. Romania, 1913, T. 42, No. 168, 593-598.

Moller, 2007 - Moller J. J. Denmark and the Crusades, 1400-1650. Leiden, 2007.

Necrologie - Nécrologie. Annales du Midi: revue archéologique, historique et philologique de la France méridionale. 1909. T. 21. Nº1, 128-129.

Riant, 1865 - Riant $P$. Expeditions et pelerinages des Scandinaves en terre sainte au temps des croisades. Paris, 1865 .

Rohricht, 1889 - Röhricht R. Graf Paul Riant. Zeitschrift des Deutschen Palästina-Vereins, 1889, No. 12, 174-80.

Salin, 1954 - Salin É. Notice sur la vie et les travaux de M. Louis Bréhier, membre de l'Académie. Comptes rendus des séances de l'Académie des Inscriptions et Belles-Lettres, 98e année, 1954, N. 2, 72-185.

Добиаш-Рождественская, 1924 - Добиаш-Рождественская О.A. Западные паломничества в средние века. Л.: Брокгауз-Ефрон, 1924.

\section{References}

Dobiash-Rozhdestvenskaya, 1924 - Dobiash-Rozhdestvenskaya O.A. (1924). Zapadnye palomnichestva v srednie veka. Leningrad: Brokgauz-Efron.

Barthelemy, 1898 - Barthélémy A. (1898). Ludovic Lalanne. Bibliothèque de l'école des chartes. T. 59, 589-598.

Bataillon, 1969 - Bataillon Ml. (1969). D.R. Menéndez Pidal (1869-1968). Bulletin Hispanique, T. 71, No. 1-2, 441-451.

Brehier, 1907 - Brehier L. (1907). L'Eglise et l'Orient au Moyen Age. Les croisades. Paris: Librairie Victor Lecoffre.

Charle, Telkes, 1988 - Charle C., Telkès E. Bédier (Charles, Marie, Joseph) (1988). Les professeurs du Collège de France - Dictionnaire biographique 1901-1939. Paris: Institut national de recherche pédagogique, 31-32.

Connors, 1998 - Connors R.J. (1998). The rhetoric of citation systems Part I: The development of annotation structures from the renaissance to 1900. Rhetoric Review, 17: 1, 6-48.

Connors, 1999 - Connors R.J. (1999). The rhetoric of citation systems - Part II: Competing epistemic values in citation. Rhetoric Review. 17:2, 219-245.

D’ Hervey de Saint Denys, 1888 - D' Hervey de Saint Denys L. (1888). Éloge funèbre de M. le comte Paul-Édouard-Didier Riant, membre de l'Académie. Comptes rendus des séances de l'Académie des Inscriptions et Belles-Lettres, 32e année, N. 6, 473-476.

Grafton, 1994 - Grafton A. (1994). The Footnote from De Thou to Ranke. History and Theory, vol. 33, no. 4, 53-76.

Lot, 1913 - Lot F. (1913). Joseph Bédier, Les légendes épiques. Recherches sur la formation des Chansons de geste; 1908-1913. Romania, T. 42, No. 168, 593-598.

Moller, 2007 - Moller J.J. (2007). Denmark and the Crusades, 1400-1650. Leiden.

Necrologie - Nécrologie (1909). Annales du Midi: revue archéologique, historique et philologique de la France méridionale. T. 21. Nº $81,128-129$.

Riant, 1865 - Riant $P$. (1865). Expeditions et pelerinages des Scandinaves en terre sainte au temps des croisades. Paris.

Rohricht, 1889 - Röhricht R. (1889). Graf Paul Riant. Zeitschrift des Deutschen PalästinaVereins, No. 12, 74-80.

Salin, 1954 - Salin É. (1954). Notice sur la vie et les travaux de M. Louis Bréhier, membre de l'Académie. Comptes rendus des séances de l'Académie des Inscriptions et Belles-Lettres, 98e année, N. 2, 172-185. 


\section{Анализ справочного аппарата как методика изучения научных связей на примере творчества О. А. Добиаш-Рождественской (1874-1939)}

Константин Антонович Миненко а, *

${ }^{\text {a } С а н к т-П е т е р б у р г с к и и ̆ ~ г о с у д а р с т в е н н ы и ̆ ~ у н и в е р с и т е т, ~ Р о с с и и ̆ с к а я ~ Ф е д е р а ц и я ~}$

Аннотация. В статье будет раскрыта проблематика использования метода анализа справочного аппарата. Мы продемонстрируем, каким образом эта методика может использоваться при изучении наследия отечественных историков. В данной статье будет анализироваться работа выдающегося историка и палеографа О. А. Добиаш-Рождественской «Западные паломничества в Средние века». Через ссылки в этой работе мы проследим, какие исследования оказали наибольшее влияние на автора при ее написании. Также мы рассмотрим сами эти исследования и их авторов, их восприятие истории и научный бэкграунд. Исходя из полученного результата, мы сделаем некоторые выводы относительно влияния французской и немецкой историографических традиций на отечественную историческую науку.

Ключевые слова: история науки, Добиаш-Рождественская, медиевистика, справочный аппарат.

\footnotetext{
${ }^{*}$ Корреспондирующий автор

Адреса электронной почты: koxminenko@gmail.com (К.А. Миненко)
} 